\title{
Analisis Lanjut Pemanfaatan Empiris Ramuan Seledri (Apium graveolens L) oleh Penyehat Tradisional
}

\section{A Study on Empirical Utilization of Celery (Apium graveolens L) as a Raw Material for Traditional Medicines by Traditional Healer}

\author{
Lestari Handayani $^{1^{*}}$, Lucie Widowati ${ }^{2}$ \\ ${ }^{I}$ Puslitbang Humaniora dan Manajemen Kesehatan, Balitbangkes, Kemenkes R.I, Jakarta, Indonesia \\ ${ }^{2}$ Puslitbang Sumber Daya dan Pelayanan Kesehatan, Balitbangkes, Kemenkes R.I, Jakarta, Indonesia \\ *E-mail:lestarimail@yahoo.com.sg
}

Diterima: 17 April 2019

Direvisi:18 Juni 2019

Disetujui: 2 September 2019

\begin{abstract}
Abstrak
Seledri (Apium graveolens L) adalah tumbuhan yang sangat populer sebagai bahan sayur sop dan banyak macam menu sayuran lainnya. Seledri memiliki manfaat sebagai tanaman obat, dan khasiat tersebut sudah dikenal diberbagai tempat di seluruh dunia. Riset Tumbuhan Obat dan Jamu (Ristoja) yang dilakukan pada tahun 2012, 2015, dan 2017 telah mengumpulkan ribuan ramuan dan diantaranya mengandung seledri. Analisis lanjut ini mempelajari lebih mendalam pemanfaatan empiris seledri sebagai bahan obat tradisional oleh penyehat tradisional (Hattra) melalui wawancara dan observasi. Berdasarkan data Ristoja tersebut ditemukan 90 ramuan dan diantaranya terdapat 20 nama lokal ramuan yang yang dimanfaatkan oleh Hattra. Pemanfaatan empiris seledri oleh Hattra teridentifikasi untuk pengobatan 10 jenis penyakit, terbanyak digunakan untuk pengobatan hipertensi atau tekanan darah tinggi dan telah diketahui justifikasi ilmiah melalui literatur. Seledri cukup aman meskipun tetap ada kontra indikasi yang harus diperhatikan. Disarankan pemanfaatan seledri untuk swa medikasi hipertensi ringan dengan pengawasan petugas kesehatan dan cara penggunaanya dapat disosialisasikan melalui kegiatan promotif pada kegiatan posyandu lansia.
\end{abstract}

Kata kunci: Seledri; Riset Tumbuhan Obat dan Jamu; Penyehat tradisional

\begin{abstract}
Celery (Apium graveolens $L$ ) is a very popular plant as a soup and many other vegetable menus. Celery has benefits as a medicinal plant and the efficacy has been known worlwide. Research on Medicinal Plants and Herbs (Ristoja) conducted in 2012, 2015, and 2017 has collected thousands of herbs and some of them contain celery. This study carried out further analysis on the empirical use of celery as an ingredient of traditional medicine by traditional healers (Hattra) through interviews and observations. Based on Ristoja's data, they found 90 herbs and among them there were 20 local names of herbs which are used by Hattra. The celery by Hattra was empirically identified for 10 types of diseases treatment. It was used mostly for hypertension or high blood pressure treatment and justificatied scientifically through other scientific literatures. It was recommended that celery could be use for self-medication a mild hypertension patient. Celery was safe although there are still contra indications. The celery treatment should be socialized through promotive activities in elderly posyandu activities remain under supervision of health workers.
\end{abstract}

Keywords: Celery; Research of medicinal plant and jamu; Traditional healer 


\section{PENDAHULUAN}

Riset Kesehatan Dasar (Riskesdas) tahun 2013 mengungkapkan tentang pemanfaatan Pelayanan Kesehatan Tradisional (Yankestrad). Sebanyak 30,4\% atau 89.753 dari 294.962 Rumah Tangga (RT) di Indonesia memanfaatkan Yankestrad. Pemanfaatan Yankestrad tertinggi di Kalimantan Selatan $(63,1 \%)$ dan terendah di Papua Barat (5,9\%). Berdasarkan jenisnya, Yankestrad ramuan yang dimanfaatkan oleh RT sebanyak 49,0\% sedangkan yang terbanyak adalah keterampilan tanpa alat $(77,8 \%)$. Pelayanan kesehatan tradisional dengan menggunakan ramuan, keterampilan dengan alat, keterampilan tanpa alat yang diberikan oleh penyehat tradisional (hattra) dilakukan dengan alasan utama untuk menjaga kesehatan/kebugaran, kecuali Yankestrad keterampilan menggunakan pikiran dengan alasan pemanfaatannya berdasarkan tradisi/ kepercayaan. ${ }^{1}$

Data Riskesdas 2018 menunjukkan bahwa pemanfaatan yankestrad pada seluruh masyarakat usia diatas 1 tahun, sebesar $32,4 \%$, upaya mendatangi tenaga hattra sebanyak $98,5 \%$ dan sisanya mendatangi tenaga kesehatan (nakes). Tenaga kesehatan yang didatangi diantaranya adalah nakes tradisional dan nakes lain yang berpendidikan. ${ }^{2}$

Saat ini Yankestrad diatur dalam Peraturan Pemerintah Republik Indonesia Nomor 103 Tahun 2014 tentang Pelayanan Kesehatan Tradisional. Salah satu jenis pelayanan tradisional adalah pelayanan kesehatan tradisional empiris yaitu penerapan kesehatan tradisional yang manfaat dan keamanannya terbukti secara empiris. ${ }^{3}$ Peraturan tersebut menyatakan bahwa Yankestrad empiris diselenggarakan oleh penyehat tradisional atau hattra, yang sebelumnya biasa disebut sebagai pengobat tradisional atau battra. Penyehat tradisional ramuan membantu memelihara kesehatan masyarakat menggunakan obat tradisional atau ramuan yang disediakan dari bahan berupa tumbuhan, bahan hewan, bahan mineral, sediaan sarian (galenik), atau campuran dari bahan tersebut. ${ }^{3}$ Banyak tumbuhan yang digunakan sebagai bahan obat tradisional untuk menanggulangi penyakit, salah satu diantaranya adalah seledri (Apium graveolens L). Seledri termasuk famili Apiaceae tanaman ini dikenal antara lain dengan nama seledri (Indonesia); sledri (Jawa), saledri, sederi, daun soh atau daun sop (Sunda). Tanaman ini tumbuh subur di dataran rendah sampai ke pegunungan mencapai $900 \mathrm{~m}$ di atas permukaan laut. Perkebunan seledri di Indonesia terdapat di daerah berhawa sejuk yaitu Brastagi, Sumatera Utara dan Jawa Barat yang tersebar di Pacet, Pangalengan dan Cipanas. ${ }^{4}$ Secara umum seledri lebih dikenal oleh masyarakat sebagai sayur yang dimanfaatkan untuk berbagai jenis masakan antara lain sayur sop.

Berbagai budaya terbukti telah memanfaatkan seledri sebagai bahan ramuan termasuk beberapa etnis di Indonesia. Balai Besar Penelitian dan Pengembangan Tanaman Obat dan Obat Tradisional (B2P2TOOT) telah melakukan Riset Tumbuhan Obat dan Jamu (Ristoja) pada tahun 2012, 2015, dan 2017 dan berhasil mengumpulkan data pengetahuan etnofarmakologi, ramuan Obat Tradisional (OT) dan Tumbuhan Obat (TO) di berbagai etnis di Indonesia. Ristoja menghasilkan informasi yang luar biasa banyak. Tulisan ini merupakan analisis lanjut data Ristoja tahun 2012, 2015, dan 2017 yang memberikan gambaran pemanfaatan empiris seledri oleh hattra baik dalam penggunaan ramuan maupun pemanfaatannya untuk berbagai penyakit. ${ }^{5,6,7}$

\section{METODE}

Data Ristoja yang telah terkumpul disimpan di Laboratorium Manajemen Data (Mandat) Badan Litbang Kesehatan sesuai 
dengan kebijakan Badan Litbang Kesehatan. Data Ristoja dikumpulkan dengan cara wawancara kepada hattra dan pengamatan di lapangan, baik terhadap praktek pengobatan oleh hattra serta observasi tumbuhan obat yang digunakan.

Potongan data Ristoja yang telah diseleksi hanya memuat data berisi tumbuhan seledri sebagai bahan tunggal atau salah satu bahan dalam ramuan. Selanjutnya dilakukan analisis secara deskriptif terhadap data yang diperoleh. Sumber informasi Ristoja terkait ramuan dan tanaman obat diperoleh dari narasumber yaitu penyehat tradisional di setiap titik pengamatan yang telah ditentukan. Analisis lanjut ini tidak membutuhkan ijin etik karena ijin dari Komisi Etik telah diperoleh pada penelitian Ristoja sebelumnya.

\section{HASIL DAN PEMBAHASAN}

\section{Gambaran pemanfaatan seledri dalam ramuan Ristoja}

Pada Ristoja, hattra di setiap titik pengamatan (lokus) dicari sekitar 5 orang yang diperoleh berdasarkan informasi masyarakat setempat yang dapat dipercaya. Berikut gambaran pelaksanaan Ristoja tahun 2012, 2015 dan 2017.

Tabel 1. Pelaksanaan Ristoja tahun 2012, 2015, dan 2017

\begin{tabular}{lccc}
\hline Uraian & $\begin{array}{c}\text { Tahun } \\
\mathbf{2 0 1 2}\end{array}$ & $\begin{array}{c}\text { Tahun } \\
\mathbf{2 0 1 5}\end{array}$ & $\begin{array}{c}\text { Tahun } \\
\mathbf{2 0 1 7}\end{array}$ \\
\hline Provinsi & 26 & 24 & 11 \\
Kabupaten & - & 125 & 65 \\
Etnis & 209 & 96 & 100 \\
Titik pengamatan & 254 & 100 & 100 \\
Hattra & 1324 & 525 & 505 \\
Ramuan & 15.773 & 10.047 & 6.193 \\
Tumbuhan obat & 19.738 & 19.871 & 11.218 \\
\hline Sumber: Diolah dari data primer Ristoja tahun 2012,2015, \\
dan 2017
\end{tabular}

Hasil pengumpulan data Ristoja di seluruh provinsi di Indonesia selama 3 tahun berasal dari 405 etnis, 2.354 hattra dan 32.013 ramuan dan ribuan tumbuhan obat.
Dilakukan seleksi data Ristoja dengan kandungan bahan seledri pada ramuan. Tabel 1. menunjukkan bahwa tahun 2012 telah dilakukan penelitian di 26 provinsi yang terdiri dari 209 etnis serta ada 1324 hattra yang didatangi untuk dilakukan wawancara dan observasi. Jumlah tersebut merupakan yang terbanyak dibanding tahun 2015 dan 2017.,6,7 Dilakukan seleksi terhadap data Ristoja dalam 3 tahun kegiatan dengan mengambil ramuan yang mengandung seledri. Jumlah hattra, ramuan dan data jenis tumbuhan obat yang diperoleh dalam Ristoja sangat banyak namun pemanfaatan seledri oleh hattra ternyata tidak terlalu banyak. Berikut pada Tabel 2 . gambaran pemanfaatan seledri dalam ramuan hattra hasil data Ristoja.

Tabel 2. Pemanfaatan seledri dalam ramuan Ristoja

\begin{tabular}{lccc}
\hline Uraian & $\begin{array}{c}\text { Tahun } \\
\mathbf{2 0 1 2}\end{array}$ & $\begin{array}{c}\text { Tahun } \\
\mathbf{2 0 1 5}\end{array}$ & $\begin{array}{c}\text { Tahun } \\
\mathbf{2 0 1 7}\end{array}$ \\
\hline Provinsi & 6 & 12 & 5 \\
Kabupaten & 6 & 12 & 6 \\
Etnis & 7 & 17 & 8 \\
Hattra & 12 & 66 & 12 \\
Nama ramuan & 7 & 11 & 8 \\
Ramuan & 12 & 66 & 12 \\
\hline
\end{tabular}

Sumber: Diolah dari data primer Ristoja tahun 2012, 2015, dan 2017

Hasil seleksi data menunjukkan bahwa Ristoja tahun 2012 hanya terdapat 12 ramuan yang mengandung seledri dari 6 provinsi (Sumatera Selatan, Bengkulu, Sulawesi Tengah, Sulawesi Tenggara, Maluku, Papua) yang berasal dari 12 hattra di 7 etnis. Pada tahun 2015 ditemukan 66 ramuan dari 66 hattra yang berasal dari 17 etnis di 12 provinsi (Sumatera Utara, Riau, Sumatera Selatan, Lampung, Jawa Barat, Jawa Tengah, Jawa Timur, Kalimantan Timur, Sulawesi Utara Sulawesi Selatan, Sulawesi Tenggara, Maluku). Pada tahun 2017 ditemukan 12 ramuan yang berasal dari 12 hattra dari 8 etnis di 5 provinsi (Nusa Tenggara Timur, Kalimantan Timur, Sulawesi Tengah, Maluku, Papua). 
Sejumlah ramuan terdiri dari seledri tunggal atau campuran dengan tanaman obat lain, beberapa mempunyai nama ramuan yang sama. Data tahun 2012 menunjukkan dari 12 ramuan terdiri dari 7 nama ramuan dan 66 ramuan seledri terdiri dari 11 nama ramuan (tahun 2015), serta dari 12 ramuan terdiri dari 8 nama ramuan (tahun 2017).

Data Ristoja menunjukkan ada 90 kasus yang diberi ramuan seledri dari lebih tiga puluh ribu ramuan yang tercatat. Ramuan seledri terbanyak terdapat pada Ristoja tahun 2015, kemungkinan dikarenakan pengumpulan Ristoja tahun 2015 banyak dilakukan pada titik pengamatan hattra di Pulau Jawa dan Sumatera. Sebagaimana diketahui bahwa perkebunan seledri di Indonesia didapatkan di daerah yang berhawa sejuk yaitu di Brastagi, Sumatera Utara dan di Jawa Barat yang tersebar di Pacet, Pangalengan dan Cipanas.

\section{Pemanfaatan ramuan seledri oleh hattra}

Enumerator yang melakukan wawancara kepada hattra telah menanyakan pemanfaatan ramuan seledri dalam pelayanan yang diberikan. Selanjutnya dilakukan pengkodean tentang manfaat sesuai keterangan dari hattra kedalam kode yang disediakan untuk data Ristoja. Selain dilakukan pengkodean, juga dicatat keluhan penyakit sesuai yang diungkapkan oleh hattra.

Hasil wawancara menunjukkan bahwa pengobatan yang dilakukan oleh hattra memiliki istilah penyakit yang mirip dengan diagnosa penyakit di dunia medis modern (kedokteran) seperti stroke, diabetes, asma, darah tinggi, hipertensi (Tabel 3). Cara hattra melakukan diagnosa sebenarnya tidak sejalan dengan ketentuan Kementerian Kesehatan karena menurut Permenkes No. 61 tahun 2016 tentang Pelayanan Kesehatan Tradisional Empiris, bahwa hattra diharapkan memberikan pelayanan dalam rangka upaya promotif dan preventif. ${ }^{8}$ Hasil
Ristoja memberikan gambaran berbeda yaitu hattra melakukan tindakan kuratif berdasar diagnosa yang ditegakkan sendiri atau atas hasil informasi tentang diagnosa pasien yang telah mendapat pelayanan di fasilitas kesehatan formal. Diagnosa penyakit seharusnya dilakukan oleh tenaga kesehatan yang kompeten dan membutuhkan peralatan kesehatan untuk penentuannya seperti kadar asam urat dengan uji laboratorium, darah tinggi dengan pemeriksaan tekanan darah.

Beberapa masalah kesehatan diobati berdasar keluhan pasien seperti sesak napas, sulit berak, dan kejang-kejang. Ditemukan 2 (dua) istilah lokal untuk masalah kesehatan yang ditangani dengan ramuan seledri yaitu "tambak awak" dan "inamia lagangge". Hal ini lebih sesuai dengan Peraturan Pemerintah No. 103 tahun 2014 tentang yankestrad bahwa hattra hanya memberikan pelayanan sesuai dengan kemampuannya. ${ }^{3}$

\section{Tabel 3. Jumlah nama lokal penyakit yang diobati dengan seledri pada Ristoja tahun 2012, 2015, dan 2017}

\begin{tabular}{|c|c|c|c|c|c|}
\hline \multicolumn{6}{|c|}{ Nama Lokal Penyakit } \\
\hline $\begin{array}{c}\text { Tahun } \\
2012\end{array}$ & $\%$ & $\begin{array}{c}\text { Tahun } \\
2015\end{array}$ & $\%$ & $\begin{array}{c}\text { Tahun } \\
2017\end{array}$ & $\%$ \\
\hline $\begin{array}{c}\text { Menor- } \\
\text { malkan } \\
\text { darah }\end{array}$ & 33,3 & $\begin{array}{l}\text { Darah } \\
\text { tinggi }\end{array}$ & 34,8 & $\begin{array}{l}\text { Darah } \\
\text { tinggi }\end{array}$ & 25,0 \\
\hline Stroke & 16,7 & Asma & 33,3 & $\begin{array}{l}\text { Kejang- } \\
\text { kejang }\end{array}$ & 25,0 \\
\hline $\begin{array}{l}\text { Asam } \\
\text { urat }\end{array}$ & 8,3 & $\begin{array}{c}\text { Hiperten } \\
\text { si, tensi }\end{array}$ & 12,1 & asma & 16,7 \\
\hline $\begin{array}{l}\text { Darah } \\
\text { tinggi }\end{array}$ & 8,3 & $\begin{array}{l}\text { Sesak } \\
\text { nafas }\end{array}$ & 7,5 & $\begin{array}{c}\text { Tekanan } \\
\text { darah } \\
\text { tinggi }\end{array}$ & 8,3 \\
\hline $\begin{array}{c}\text { Penurun } \\
\text { tekanan } \\
\text { darah }\end{array}$ & 8,3 & $\begin{array}{l}\text { Panas } \\
\text { dalam }\end{array}$ & 6,1 & $\begin{array}{l}\text { Sakit } \\
\text { mata }\end{array}$ & 8,3 \\
\hline $\begin{array}{c}\text { Jantung } \\
\text { lemah }\end{array}$ & 8,3 & $\begin{array}{c}\text { Tambar } \\
\text { awak }\end{array}$ & 4,5 & Stroke & 8,3 \\
\hline $\begin{array}{c}\text { Obat } \\
\text { darah } \\
\text { rendah }\end{array}$ & 8,3 & $\begin{array}{l}\text { Sulit } \\
\text { berak }\end{array}$ & 1,5 & $\begin{array}{c}\text { Inamia } \\
\text { Lagangge }\end{array}$ & 8,3 \\
\hline Diabetes & 8,3 & & & & \\
\hline
\end{tabular}

Sumber: diolah dari data Ristoja Tahun $2012(\mathrm{n}=12)$, $2015(\mathrm{n}=66)$ dan $2017(\mathrm{n}=12)$ 
Ada beberapa pelayanan promotif dan preventif yang dilakukan hattra meskipun lebih banyak pelayanan kuratif yang diberikan menggunakan ramuan berbahan seledri. Berdasar temuan Ristoja tahun 2012, 2015 dan 2017, telah dilakukan pengelompokkan penyakit oleh enumerator terlatih. Enumerator melakukan pengkodean di lapangan sesuai dengan kode penyakit yang disediakan. Pengelompokan pemanfaatan ramuan seledri dapat dilihat pada Tabel 4.

Tabel 4. Pemanfaatan ramuan seledri oleh hattra berdasar kode penyakit, Ristoja tahun 2012, 2015, dan 2017

\begin{tabular}{cccccc}
\hline \multicolumn{5}{c}{ Kode Penyakit } \\
\hline $\begin{array}{c}\text { Tahun } \\
\mathbf{2 0 1 2}\end{array}$ & $\mathbf{\%}$ & $\begin{array}{c}\text { Tahun } \\
\mathbf{2 0 1 5}\end{array}$ & $\mathbf{\%}$ & $\begin{array}{c}\text { Tahun } \\
\mathbf{2 0 1 7}\end{array}$ & $\mathbf{\%}$ \\
\hline $\begin{array}{c}\text { Rematik, } \\
\text { asam urat }\end{array}$ & 8,3 & $\begin{array}{c}\text { Darah } \\
\text { tinggi }\end{array}$ & 47,0 & $\begin{array}{c}\text { Darah } \\
\text { tinggi }\end{array}$ & 41,7 \\
Hipertensi & 16,7 & $\begin{array}{c}\text { Demam/ } \\
\text { panas }\end{array}$ & 6,1 & $\begin{array}{c}\text { Demam/ } \\
\text { panas }\end{array}$ & 25,0 \\
Jantung & 8,3 & $\begin{array}{c}\text { Sakit } \\
\text { pinggang }\end{array}$ & 4,5 & $\begin{array}{c}\text { Sakit } \\
\text { mata }\end{array}$ & 8,3 \\
DM & 8,3 & $\begin{array}{c}\text { Sembelit/ } \\
\text { konstipasi } \\
\text { Sesak } \\
\text { napas }\end{array}$ & 1,5 & $\begin{array}{c}\text { Sesak } \\
\text { napas }\end{array}$ & 16,7 \\
Stroke, & 16,7 & $\begin{array}{c}\text { Stroke, } \\
\text { lumpuh }\end{array}$ & 8,3 \\
lumpuh & - & - & - & - \\
Darah & 33,3 & - & & & \\
\hline tinggi
\end{tabular}

Sumber: diolah dari data Ristoja Tahun $2012(\mathrm{n}=12)$, $2015(\mathrm{n}=66)$ dan $2017(\mathrm{n}=12)$

Data Ristoja menunjukkan pemanfaatan ramuan seledri secara empiris oleh hattra. Data tersebut menunjukkan bahwa ramuan seledri banyak digunakan untuk menanggulangi bermacam macam penyakit yaitu rematik/asam urat, darah tinggi, demam, sakit pinggang, sembelit, sesak nafas, sakit mata, stroke/lumpuh dan kencing manis. Data lain menunjukkan bahwa manfaat empirik seledri sebagai ramuan tunggal tidak jauh berbeda yaitu sebagai pelancar buang air kecil, asam urat, gangguan kelemahan syaraf, penghilang sakit (sakit kepala). Khasiat lain yang diakui adalah sebagai antioksidan, antibakteri, anti platelet, anti proliferative, gangguan pernafasan, konstipasi, serak, inflamasi, luka, lumbago, gangguan pengeluaran ASI dan aprodisiak. ${ }^{9}$ Daun, tangkai dan biji tanaman seledri digunakan untuk rematik, gout, radang saluran kencing, rematoid artritis, diuretik, batu kandung kemih, profilaksis agitasi syaraf, kekurangan nafsu makan dan cacingan. ${ }^{10}$

Seledri tanaman asli lembah sungai Mediterranian ini bahkan sudah dikenal sejak sejarah awal Mesir, Yunani dan Romawi dikenal sebagai sayuran yang diambil batangnya. Berdasar dokumen dari kesusastraan kuno disebutkan bahwa seledri telah digunakan untuk keperluan pengobatan sejak 850 sebelum masehi. Biji seledri digunakan oleh tabib Ayurveda kuno untuk mengobati demam, flu, penyakit pencernaan, beberapa tipe arthritis, penyakit limpa dan hati. ${ }^{11}$

\section{Hipertensi dan jantung}

Gangguan kesehatan yang dilayani hattra dengan ramuan mengandung bahan seledri, terbanyak adalah hipertensi dan darah tinggi. Ada dua istilah yang dipakai hattra yang sebenarnya adalah sama, oleh karena itu untuk menghitung jumlah kasus/ramuan maka digabungkan untuk istilah darah tinggi atau hipertensi. Pada data Ristoja tahun 2012, pengumpulan dan pengkodean ditemukan istilah hipertensi dan darah tinggi. Gabungan keduanya sebanyak 6 atau $50 \%$. Data Ristoja selama 3 tahun tentang pemanfaatan seledri menyatakan bahwa sebagian besar digunakan untuk mengobati darah tinggi yaitu sebesar 50\% tahun 2012, 47\% pada tahun 2015 dan $41,7 \%$ pada tahun 2017. Penggunaan daun seledri dilakukan dengan cara pembuatan sederhana seperti jus, rebusan, dimakan sebagai sayur sampai bentuk ekstrak. 5,6,7 Pengobatan sebagai penurun tekanan darah tinggi atau hipertensi dan obat jantung dapat dijelaskan dari hasil penelitian terhadap hewan coba yang diinduksi fruktosa. Sebuah penelitian 
dilakukan sebagai evaluasi efek ekstrak alkohol daun seledri pada parameter kardiovaskular (tekanan darah sistol dan denyut jantung) serta profile lipid. Disimpulkan bahwa ekstrak daun seledri mengurangi tekanan darah sistol, mengurangi kadar kolesterol, trigliserida, Low Density Lipoprotein (LDL) dan Very Low Density Lipoprotein (VLDL) pada hewan model hipertensi fruktosa. ${ }^{12} \mathrm{Uji}$ tersebut dilakukan terhadap 5 kelompok yaitu (1) grup kontrol, (2) grup yang menerima $200 \mathrm{mg} / \mathrm{kg}$ bb. ekstrak daun seledri, (3) grup yang menerima fructose $10 \%$ dan (4) grup yang menerima fruktosa dan $100 \mathrm{~g} / \mathrm{kg} \mathrm{bb}$, (5) grup menerima fructose dan $200 \mathrm{mg} / \mathrm{kg}$ bb. ekstrak (masing-masing $\mathrm{n}=8$ ). Hasil uji menunjukkan peningkatan tekanan darah sistol pada kelompok fruktosa secara signifikan dibandingkan kelompok kontrol ( $\mathrm{P}<0,01)$. Tekanan darah sistol pada kelompok yang menerima fruktosa + ekstrak $100 \mathrm{mg} / \mathrm{kg}$ bb., fruktosa + ekstrak 200 $\mathrm{mg} / \mathrm{kg}$ bb., dibandingkan dengan kelompok fruktosa, menunjukkan penurunan signifikan. Tingkat denyut jantung pada kelompok ini tidak menunjukkan perbedaan yang signifikan. Kolesterol, trigliserida, LDL dan VLDL pada kelompok fruktosa meningkat secara signifikan, namun efek ini secara signifikan menurun pada kelompok ekstrak. Tingkat Hight Density Lipoprotein (HDL) pada kelompok fruktosa tidak menunjukkan perbedaan, sementara pada kelompok yang menerima ekstrak meningkat secara signifikan. ${ }^{12}$

Banyak penelitian eksperimental menunjukkan bahwa Apium graveolens menurunkan jumlah kadar kolesterol, trigliserida, LDL dan VLDL serum secara signifikan dan peningkatan kadar HDL. Apium graveolens pada penelitian eksperimental juga mengurangi pembentukan plak arteri, mekanismenya diduga adalah menurunkan lipid termasuk penghambatan biosintesis kolesterol di hati, meningkatkan ekskresi asam empedu feses dan meningkatkan lesitin plasma (aktivitas kolesterol asiltransferase) dan mengurangi penyerapan lemak di usus. Beberapa penulis menyebutkan bahwa efek menurunkan lipid darah dikaitkan dengan senyawa 3-nbutylphthalide atau $(3 \mathrm{nB})$ yang diisolasi dari Apium graveolens, namun ekstrak aktif bebas dari 3-n-butylphthalide telah dilaporkan memiliki khasiat penurunan lipid. Sebaliknya, kromatografi lapis tipis menunjukkan bahwa senyawa polar dengan rantai samping gula atau asam amino bisa menjadi konstituen hipokolesterolaemik dari ekstrak seledri. ${ }^{10}$

Uji efek hipolipidemik yang bermanfaat untuk kardiovaskular dilakukan terhadap ekstrak air dan etanol dari seledri 0,5-15 $\mathrm{mg} / \mathrm{kg}$ bb. Hasil uji menunjukkan penurunan tekanan darah kelinci teranastesi melalui mekanisme blok atropine $(0,3 \mathrm{mg} / \mathrm{kg}$ bb. $)$. Efek menurunkan tekanan darah dari ekstrak air seledri sebesar $(14,35 \pm 2,94 \%)$ lebih kecil dibandingkan ekstrak etanol $(45,79 \pm$ $10,86 \%$ ) demikian pula dengan penurunan amplitude. $^{13}$

Seledri juga digunakan mengobati penyakit jantung. Aktifitas seledri terhadap kardiovaskular telah dibuktikan melalui penelitian. Telah dilakukan penelitian efek apigenin pada vasorelaksasi endotel pada cincin aorta tikus terisolasi yang terpapar anion superoksida yang diproduksi oleh pirogallol, serta mekanismenya. Aorta toraks tikus Sprague-Dawley jantan dibedah dengan cepat dan diukur efek apigenin terhadap tegangan cincin aorta yang diberi $500 \mu \mathrm{M}$ pyrogallol sebagai penyebab kerusakan oksidatif. Apigenin terbukti memiliki efek kardiovaskular, namun efek apigenin pada aorta yang dilukai oleh oksidan eksogen tidak diketahui. Hasil penelitian menunjukkan bahwa pyrogallol menurunkan vasorelaksasi endotelium pada aorta tikus melalui stres oksidatif, yang 
nyata dilemahkan oleh apigenin. Mekanisme kemungkinan melalui melemahnya stres oksidatif dan pengurangan NO. ${ }^{14}$

Penelitian yang dilakukan Sakinah, adalah untuk mengetahui pengaruh rebusan seledri terhadap penurunan tekanan darah pada klien hipertensi di Puskesmas Pangkajene Kabupaten Sidendreng Rappang. Populasi pada penelitian ini adalah penderita hipertensi di wilayah kerja Puskesmas Pangkajene bulan Januari 2018 sebanyak 102 orang, dengan sampel sebanyak 15 responden yang dilakukan secara purposive sampling. Hasil penelitian menunjukkan adanya pengaruh pemberian rebusan daun seledri terhadap penurunan tekanan darah pada penderita hipertensi nilai $(p=0,000){ }^{15}$ Rebusan daun seledri juga dimanfaatkan lansia penderita hipertensi di Dusun Gogo Dalem Barat. Penelitian tersebut membuktikan adanya penurunan tekanan darah baik sistol maupun diastole. ${ }^{16}$

Telah dilakukan penelitian untuk melihat pemberian bawang putih dan seledri terhadap tekanan darah pasien hipertensi di puskesmas Batua kota Makassar. Hasil penelitian menunjukkan bahwa pemberian bawang putih dan seledri berpengaruh terhadap penurunan tekanan darah penderita hipertensi. Persentase penurunan paling tinggi adalah pada kelompok seledri (72\%). Perbedaan rata-rata tekanan darah sistolik antara kelompok bawang putih dan kelompok seledri terjadi pada pengukuran hari kedua, ketiga dan keempat $(\mathrm{p}<0,05) .{ }^{17}$

Pemanfaatan rebusan seledri terbukti efektif menurunkan hipertensi para lansia hipertensi di Posyandu. Beberapa kandungan seledri yaitu magnesium, pthalides, apigenin, kalium dan asparagin penting dalam menurunkan tekanan darah. Magnesium dan pthalides berperan melenturkan pembuluh darah, apigenin mencegah penyempitan pembuluh darah dan tekanan darah tinggi. Kalium dan asparagin bersifat diuretik sehingga volume darah berkurang. ${ }^{18}$

\section{Rematik dan asam urat}

Penyakit degeneratif lain yang ditangani dengan seledri berdasar Ristoja tahun 2012, 2015, dan 2017 yaitu rematik dan asam urat. Pemanfaatan sebagai obat rematik dan asam urat tersebut sesuai dengan temuan lain yang menyatakan bahwa daun, tangkai dan biji tanaman seledri dapat digunakan untuk mengobati rematik/asam urat, gout, rematoid arthritis. Hasil penelitian terhadap hiperurisemia, menunjukkan bahwa seledri dapat mengurangi kadar asam urat, direkomendasikan sebagai "functional food". ${ }^{19}$ Pemberian air rebusan seledri (Apium graveolens L.) dua kali sehari pada penderita gout di Rasau Jaya, menunjukkan pengurangan keluhan nyeri dan penurunan kadar asam urat. Pemberian air rebusan seledri (apium graveolens L.) ini dapat diaplikasikan sebagai intervensi mandiri keperawatan dalam menangani masalah asam urat. ${ }^{20}$ Seledri sebagai obat rematik karena memiliki efek sebagai antiinflamasi seperti hasil penelitian yang menyatakan bahwa Apium graveolens memberikan efek antiinflamasi pada tes telinga tikus dan melawan induksi karagen pada telapak kaki tikus. $^{21}$

Pemanfaatan secara empiris tanaman seledri sebagai obat rematik juga dilaporkan oleh beberapa tulisan lain dengan memanfaatkan daun, batang bahkan bonggolnya. Cara konsumsi adalah dengan dimakan sebagai lalap (mentah) atau direbus dan diminum air rebusannya. ${ }^{10}$

\section{Demam dan sesak napas}

Seledri juga dimanfaatkan dalam ramuan untuk pengobatan demam, sakit panas dan sesak napas. Pemanfaatan ini sesuai dengan pemanfaatan empiris secara tradisional di Arab dan pengobatan Islam dengan nama Karafs. Di Negara Arab terdapat 5 jenis seledri, dengan nama Bustani, Maiee, Sakhuri, Nabti dan Jabli. Seledri dikatakan dapat mengurangi nafas yang mengganggu. 
Seledri juga digunakan sebagai obat batuk dengan cara minum rebusan air seledri setelah ditambahkan madu. ${ }^{22}$

\section{Sembelit/konstipasi}

Sembelit adalah gangguan pencernaan berupa kesulitan dalam buang air besar (BAB) yang disebabkan berbagai hal. Tidak ditemukan dalam berbagai penelitian efek seledri sebagai obat konstipasi, namun pengobat tradisional mengenal dan memanfaatkan seledri untuk pengobatan penyakit gastrointestinal. Serbuk daun kering seledri diekstraksi dengan air dan etanol 96\%. Aktivitas kedua ekstrak pada kontraksi otot polos dievaluasi dengan menggunakan model tikus ileum terisolasi. Ileum tikus yang terisolasi dipasang pada 10 $\mathrm{mL}$ rendaman jaringan. Hasilnya menunjukkan bahwa konsentrasi kumulatif kedua ekstrak seledri secara statistik menghambat kontraksi ileum tikus spontan secara signifikan $(\mathrm{p}<0,01)$. Pengurangan efek kontraktil asetilkolin pada ileum terisolasi $(\mathrm{p}<0,05)$ tergantung pada dosis, sehingga terlihat hubungan dosis efek. Ekstrak etanol menunjukkan aktivitas relaksan yang jauh lebih besar daripada ekstrak air $(\mathrm{p}<0,05){ }^{22}$

Imam bin al-Qayyim, penulis buku terkenal tentang obat kenabian memberi penjelasan khasiat seledri yakni daun seledri basah akan membantu mendinginkan perut dan hati dan juga berperan sebagai diuretik dan membantu dalam masalah haid dan batu ginjal. ${ }^{21}$

\section{Diabetes melitus dan stroke/lumpuh}

Pemanfaatan seledri sebagai obat diabetes melitus dan stroke/lumpuh tidak banyak dilaporkan, namun pada Ristoja ditemukan seorang Hattra yang menyatakan menggunakan seledri untuk mengobati diabetes melitus dan stroke. Diabetes melitus pada umumnya juga terkait dengan peningkatan kadar lipid sehingga pemanfaatan seledri kemungkinan juga untuk mengurangi kadar kolesterol. Hal sama kemungkinan juga untuk pengobatan stroke seperti yang diklaim oleh 3 (tiga) orang Hattra yang menjadi informan dalam Ristoja tahun 2012 dan 2017. Stroke disebabkan oleh penyumbatan atau pecahnya pembuluh darah ke otak, akibat adanya plak dan hipertensi. Penggunaan seledri kemungkinan secara tidak langsung adalah untuk menurunkan hipertensi dan kadar kolesterol tinggi sebagai faktor yang berpengaruh terhadap kejadian stroke.

\section{Cara penyiapan ramuan}

Penggunaan seledri untuk pengobatan berdasarkan resep hattra dapat disiapkan oleh hattra atau disiapkan oleh pasien. Cara pembuatan dan penyiapan ramuan seledri cukup sederhana dan mudah dilakukan. Data Ristoja dalam 3 tahun menunjukkan bahwa ada penggunaan sebagai obat dalam (minum/makan) dalam bentuk bahan tunggal (hanya seledri) sebagai bahan ramuan namun ada pula yang dicampur dengan bahan lain. Penyiapan seledri sebagai bahan tunggal ramuan penyiapan oleh hattra adalah dengan cara: ditambah air dan direbus sampai dihasilkan air rebusan untuk diminum; dimakan mentah sebagai lalapan; direbus dan dimakan sebagai sayur; seledri diremas dengan air hangat dan air hasil remasan diminum; seledri kering rebus dengan air, minum air rebusan seledri; diminum sebagai jus seledri; seledri segar disiram air panas, tutup dan minum setelah air dingin (sampai dingin atau sampai 30 menit).

Penggunaan dengan cara minum air rebusan merupakan cara yang paling umum dilakukan. Cara penyiapan ramuan ini sesuai dengan cara tradisional yang ditemukan ditempat lain yaitu dengan cara direbus kemudian air rebusan diminum. Cara penyiapan oleh hattra bermacam-macam terhadap seledri seperti dicampur bahan lain dengan cara: dikunyah dengan diberi madu; 
dijus dengan mentimun; daun sop dan bawang putih ditumbuk, diseduh dengan air hangat, air rebusan diminum; Ditumbuk dengan timun dan bawang putih, selanjutnya air perasan diminum; Ditumbuk, campur garam, gula batu, biji selasih + air aduk; Direbus atau dijus bersama daun sisik naga, mentimun, 3 buah konje; seledri dan daun randu ditumbuk atau dijus, siram dengan air mendidih dan tambahkan gula aren; seledri dimasak sebagai bagian sayur. ${ }^{5,6,7}$

Penggunaan dengan ditambah bahan tumbuhan obat lain pada umumnya disiapkan dengan cara ditumbuk, dijus, diperas atau dimakan sebagai sayur. Cara tersebut juga ditemui di tempat lain seperti yang dilakukan masyarakat sebagai sayur, dibuat jus, ditumbuk dan diperas. disamping dimakan mentah. ${ }^{10}$

Sebagai obat luar seledri disiapkan dengan cara: seledri digerus dengan ampas teh dan dibalurkan pada leher; seledri direbus, uap dari rebusan seledri diarahkan ke mata; seledri, jaringau, daun dilem ditumbuk, tempelkan pada ubun-ubu; daun seledri diremas dengan air hangat, oleskan pada perut. Penggunaan luar seledri juga dilakukan di tempat lain yaitu ditumbuk dan dioleskan pada kulit kepala sebagai penyubur rambut dan dioleskan pada kulit sambil dipijat.

\section{Dosis dan aturan minum}

Pembuatan ramuan seledri sangat bervariasi dalam menetapkan jumlah/ dosis seledri. Hattra menyampaikan cara mengukur seledri dalam besaran yang berbeda dan tidak ada yang melakukan dengan mengukur dalam bentuk ditimbang beratnya (gram, ons, kilogram). Cara mengukur dengan takaran sederhana antara lain dalam bentuk genggam, batang, lembar daun, pucuk, rumpun, lembar, secukupnya. Cara ini umum dilakukan oleh Hattra sehingga mudah dilaksanakan oleh pasien bila harus menyiapkan sendiri di rumah.
Hasil Ristoja menunjukkan dosis seledri yang diberikan oleh hattra bagi pasien. Dosis anjuran pada umumnya diminum 1-3 kali/hari biasanya disesuaikan dengan keparahan penyakit. Berdasar informasi yang disampaikan oleh hattra, bahwa pemberian dosis ramuan seledri umumnya semakin sering dan semakin lama jika penyakit semakin parah. Pada Tabel 5 menjelaskan dosis anjuran oleh hattra seperti yang disampaikan kepada enumerator saat wawancara dan atau observasi.

Tabel 5. Dosis penggunaan seledri Ristoja tahun 2012, 2015, dan 2017

\begin{tabular}{cccc}
\hline Frekuensi & $\begin{array}{c}\text { Tahun } \\
\mathbf{2 0 1 2}\end{array}$ & $\begin{array}{c}\text { Tahun } \\
\mathbf{2 0 1 5}\end{array}$ & $\begin{array}{c}\text { Tahun } \\
\mathbf{2 0 1 7}\end{array}$ \\
\hline $1 \times$ & $16,6 \%$ & $7,6 \%$ & $33,3 \%$ \\
$2 \mathrm{x}$ & $41,7 \%$ & $30,3 \%$ & $25,0 \%$ \\
$3 \mathrm{x}$ & $41,7 \%$ & $37,9 \%$ & $41,7 \%$ \\
Lainnya & - & $24,2 \%$ & - \\
\hline
\end{tabular}

Sumber: diolah dari data Ristoja Tahun $2012(\mathrm{n}=12)$, $2015(\mathrm{n}=66)$ dan $2017(\mathrm{n}=12)$

Penggunaan seledri nampaknya cukup aman karena hattra tidak melaporkan adanya efek samping yang dialami pasien. Berdasar literatur, ada beberapa larangan atau kontra indikasi penggunaan seledri karena adanya efek yang tidak diinginkan. Minyak atsiri seledri dapat menyebabkan iritasi pada ginjal, oleh karena itu sediaan dengan minyak atsiri seledri dilarang diberikan pada penderita infeksi ginjal. Adanya infeksi jamur pada tanaman dapat menyebabkan adanya kandungan furano coumarins pada akar yang dapat meningkat sampai 200 kali pada kondisi penyimpanan. Adanya sejumlah jamur, furano coumarin yang menginfeksi seledri dapat menyebabkan timbulnya reaksi fototoksik. ${ }^{9}$

Efek alergi juga ditemui pada penggunaan seledri. Penelitian pada 20 pasien yang mengkonsumsi seledri ditemui gejala mukokutan (generalisata urtikaria dan angioedema) (90\%) dan gangguan pernapasan (35\%). Terdapat empat kasus anafilaksis sistemik. Gangguan alergi utama 
yang terkait adalah alergi pollen $(80 \%){ }^{23}$ Seledri sebaiknya diberikan secara hati-hati pada pasien sedang demam. Hal ini bertentangan dengan beberapa praktek penggunaan seledri yang dimanfaatkan sebagai obat demam. Perhatian perlu dilakukan terhadap penggunaan seledri pada wanita hamil, karena dapat mengstimulus uterus. Infus daun seledri tidak direkomendasikan digunakan oleh wanita hamil. ${ }^{24}$ Terdapat kontraindikasi penggunaan biji seledri pada wanita hamil, ibu menyusui dan pasien epilepsi. Dengan demikian perlu dihindari penggunaan seledri bersama bunga yang mengandung pollen atau bijinya yang dapat mempengaruhi kehamilan. ${ }^{24,25}$

\section{KESIMPULAN}

Pemanfaatan empiris seledri oleh hattra lebih banyak di pulau Jawa dan Sumatera karena sentra pertanian seledri ada di dua pulau tersebut dan teridentifikasi untuk menangani 10 jenis keluhan kesehatan. Seledri secara empiris banyak digunakan untuk menanggulangi bermacam macam keluhan penyakit seperti tekanan darah tinggi, rematik/asam urat, demam, sakit pinggang, sembelit, sesak nafas. Pemanfaatan terbanyak seledri untuk menurunkan gula darah atau tekanan darah tinggi. Berdasar justifikasi ilmiah dilengkapi hasil penelitian, seledri memiliki khasiat sebagai bahan ramuan hipertensi. Seledri cukup aman meskipun tetap ada kontra indikasi yang harus diperhatikan.

\section{SARAN}

Ramuan seledri dapat dimanfaatkan sebagai obat hipertensi secara swa medikasi karena hipertensi merupakan penyakit yang banyak diderita masyarakat Indonesia. Penggunaan tersebut diharapkan mengurangi komplikasi hipertensi berupa penyakit degeneratif seperti diabetes, stroke dan jantung. Manfaat dan cara penggunaan seledri untuk swa medikasi hipertensi ringan dapat disosialisasikan melalui kegiatan promotif pada kegiatan posyandu lansia dengan tetap dalam pengawasan petugas kesehatan.

\section{UCAPAN TERIMA KASIH}

Ucapan terima kasih disampaikan kepada Kepala Badan Penelitian dan Pengembangan Kesehatan Republik Indonesia yang telah memberi ijin penggunaan data Ristoja. Tidak lupa ucapan terima kasih disampaikan kepada Tim Manajemen Data telah menyediakan data terpilah untuk dianalisis.

\section{DAFTAR RUJUKAN}

1. Widowati L, Nurhayati. The use of traditional health care among Indonesian family. Health Science Journal Indonesia. 2017;8(1):30-5.

2. Badan Litbang Kesehatan. Laporan Riskesdas 2018 Nasional. Laporan Riskesdas Nasional. Jakarta: Badan Litbang Kesehatan: Jakarta; 2018.

3. Republik Indonesia. Peraturan Pemerintah Nomor 103 Tahun 2014 tentang Pelayanan Kesehatan Tradisional. Jakarta Sekretariat Negara; 2014.

4. Tanujaya S. Daftar Jornal Med Plants Res obat herbal Indonesia. Remaja Kerokhanian Sapta Darma Sragen; 2014.

5. Badan Litbang Kesehatan. Laporan Nasional Ristoja 2012. Eksplorasi pengetahuan lokal etnomedisin dan tumbuhan obat berbasis komunitas di Indonesia: Badan Litbang Kesehatan: Jakarta; 2012.

6. Badan Litbang Kesehatan. Laporan Nasional Ristoja 2015. Eksplorasi pengetahuan lokal etnomedisin dan tumbuhan obat berbasis komunitas di Indonesia. Jakarta: Badan Litbang Kesehatan; 2015.

7. Badan Litbang Kesehatan. Laporan Nasional Ristoja 2017. Eksplorasi pengetahuan lokal etnomedisin dan tumbuhan obat berbasis komunitas di Indonesia. Jakarta: Badan Litbang Kesehatan; 2017. 
8. Republik Indonesia. Peraturan Menteri Kesehatan No. 61 Tahun 2016 tentang Pelayanan Kesehatan Tradisional Empiris. Jakarta: Kementerian Kesehatan; 2016;

9. Asif HM, Akram M, Usmanghani K, Akhtar N, Shah PA, Uzair M, et al. Monograph of apium graveolens Linn. Jornal Medicinal Plants Research. 2011;5(8):1494-6.

10. Al-Snafi AE. The Pharmacology of Apium graveolens- A Review. Intenational Journal Pharmaceutical Research Scholars. 2014;3(I-1)671-7.

11. Fazal SS, Singla RK. Review on the pharmacognostical \& pharmacological characterization of Apium graveolens Linn. Indo Global Journal Pharmaucetical Sciences. 2012;2(1):36-42.

12. Dianat M, Veisi A, Ahangarpour A, moghaddam HF. The effect of hydroalcoholic celery (Apium graveolens) leaf extract on cardiovascular parameters and lipid profile in animal model of hypertension induced by fructose. Avicenna Journal of Phytomedicine .2015;5(3):203-9.

13. Brankovi S, Kitic D, Radenkovi M, Veljkovi S, Kosti M, Miladinovi B, et al. Hypotensive and cardio inhibotory effects of the aqueous and ethanol extracts of celery ( Apium graveolens, Apiaceae ). Acta Medica Mediane. 2010;49(1):13-6.

14. Jin BH, Qian LB, Chen S, Li J, Wang AP, Bruce IC et al. Apigenin protects endothelium-dependent relaxation of rat aorta against oxidative stress. European Journal Pharmacology. 2009;616:200-5.

15. Sakinah S, Azhari HK. Pengaruh rebusan daun seledri terhadap penurunan tekanan darah pada pasien hipertensi di wilayah kerja puskesmas Pangkajene Kabupaten Sidrap. Jurnal Ilmiah Kesehatan Diagnosis. 2018;12(3):261-6.

16. Arie NNM, Muntamah U, Trimawati $T$. Pengaruh pemberian air rebusan seledri pada lansia di Dusun Gogodalem Barat. Jurnal Keperawatan Komunitas. 2014;2(1):46-51.

17. Latuconsina ND, Amiruddin R Sirajuddin S. Efek pemberian bawang putih dan seledri terhadap tekanan darah pasien hipertensi di Puskesmas Batua kota Makassar. Jurnal
Kesehatan Masyarakat Mulawarman. 2019:1(1):1-8.

18. Asmawati N, Puwarti, Handayani RS. Efektivitas rebusan seledri dalam menurunkan tekanan darah pada lansia penderita hipertensi di posyandu lansia Kelurahan Pajar Bulan Kecamatan Way Tenong Lampung Barat. Jurnal Kesehatan. 2015;VI(2):130-6.

19. Dolati K, Rakhshandeh H, Golestani M, Forouzanfar F, Sadeghnia R, Sadeghnia HR. Inhibitory effects of Apium graveolens on xanthine oxidase activity and serum uric acid levels in hyperuricemic mice. Preventive Nutrition and Food Science. 2018;23(2):127-33.

20. Usman, Prasetya I, Putra GJ, Wuriani. Pengaruh pemberian air rebusan seledri (Apium Graveolens L.) terhadap kadar asam urat pada penderita gout artritis di Rasau Jaya. Health Sciences and Pharmacy Journal. 2018;2(1);1-7.

21. Al-Asmari AK Athar Md T. Kadasah SG. An updated phytopharmacological review on medicinal plant of Arab Region: Apium graveolens Linn. Pharmacognosy Review. 2018;11(21):13-8.

22. Branković S, Gočmanac-Ignjatović $M$, Kostić M, Veljković M, Miladinović B, Milutinović M, et al. Spasmolytic activity of the aqueous and ethanol celery leaves (Apium Graveolens L.) extracts on the contraction of isolated rat ileum. Acta Medica Medianae. 2015;54(2):11-5.

23. Hauser M, Roulias A, Ferreira F, Egger M. Panallergens and their impact on the allergic patient. Allergy, Asthma Clinical Immunology. 2010;6(1):1-14.

24. Kooti W, Ali-Akbari S, Majid Asadi-Samani M, Ghadery H, Ashtary-Larky D. A Review on medicinal plant of Apium graveolens. Advanced Herbal Medicine. 2014; 1(1):4859.

25. Khan IA, Abourashed EA. Leung's encyclopedia of common natural ingredients: used in food, drugs, and cosmetics. Third Edition. Oxford: A John Wiley \& Sons, IInk., Publication; 2010. 